\title{
Hubungan IL- I 0 dengan Serum Kreatinin dan Terjadinya Komplikasi pada Preeklampsia Perawatan Konservatif
}

\author{
Intan Wahyu Lasiaprillianty, Ernawati \\ Departemen Obstetri dan Ginekologi, Fakultas Kedokteran Universitas Airangga, \\ RSUD Dr. Soetomo, Surabaya
}

\begin{abstract}
ABSTRAK
Tujuan: mengetahui hubungan penurunan IL-10 dengan terjadinya peningkatan serum kreatinin (SK) dan terjadinya komplikasi preeklampsia.

Bahan dan Metode: penelitian ini merupakan analitik observasional yang dilakukan pada 30 wanita preeklampsia berat tipe dini yang dilakukan perawatan konservatif. Dilakukan pemeriksaan IL-10 pada serum darah dengan metode ELISA sebelum perawatan konservatif dan kemudian dinilai luaran maternal (SK dan komplikasi preeklampsia)

Hasil: didapatkan rerata kadar IL-10 pada preeklampsia tipe dini $0,71 \pm 0,66 \mathrm{pg} / \mathrm{mL}$, rerata luaran SK $0,83 \pm 0,29$, terjadinya komplikasi 9 kasus (edema paru, impending eklampsia, sindroma HELLP). Tidak didapatkan hubungan antara IL-10 dengan peningkatan serum kreatinin $(\mathrm{p}=0,483)$ dan komplikasi preeklampsia $(\mathrm{p}=0,828)$.

Simpulan: IL-10 bukan merupakan faktor prediktif untuk luaran maternal pada preeklampsia perawatan konservatif.
\end{abstract}

Kata kunci: interleukin-10, preeklampsia tipe dini, luaran maternal

Correspondence: Intan Wahyu Lasiaprillianty, Airlangga University-RSUD Dr. Soetomo, Jl. Prof. Dr. Moestopo 6-8 Surabaya. Telp: 08121769920. Email: intan.obg@gmail.com

\begin{abstract}
Objectives: analyze correlation decreasing of IL-10 with increasing of Creatinine serum and preeclampsia complications Materials and Methods: this is a observational analytic study on 30 pregnant women with early onset preeclampsia that managed wit expectant management. IL-10 from blood serum was measured using ELISA before expectant management and maternal outcomes were observed before delivery.

Results: mean of IL-10 level on early onset preeclampsia is 0,71 $\pm 0,66 \mathrm{pg} / \mathrm{mL}$, mean of creatinine serum $0,83 \pm 0,29$ and there was nine preeclampsia complications (pulmonary edema, impending eclampsia and HELPP syndrome). No correlation between IL-10 and creatinine serum increasing $(\mathrm{p}=0,483)$ and maternal complications $(\mathrm{p}=0,828)$.

Conclusions: IL-10 is not predictive factor for maternal outcome of early onset preeclampsia with expectant management
\end{abstract}

Keywords: interleukin-10 was not predictive factor for maternal outcome of preeclampsia with expectant management

\section{PENDAHULUAN}

Preeklampsia merupakan penyakit pada kehamilan yang didefinisikan dengan munculnya hipertensi dan proteinuria ditemukan setelah umur kehamilan 20 minggu, terjadi pada 2-8\% kehamilan. Preeklampsia merupakan komplikasi dalam kehamilan yang paling sering terjadi, dengan insiden yang semakin meningkat di dunia dan berkaitan berkaitan dengan morbiditas dan mortalitas maternal dan tercatat kematian sekitar 50. 000 di dunia. Oleh karena itu menurunkan angka kematian maternal sebesar 75\% antara tahun 1990 sampai 2015 menjadi millennium development goals dari World Health Organization (WHO). Di negara berkembang, preeklampsia menyebabkan kematian maternal (15-20\%) dan morbiditas maternal (jangka pendek dan jangka panjang), kematian perinatal, kelahiran prematur dan pertumbuhan janin terhambat dalam rahim.

Selama beberapa tahun telah dikenal teori keseimbangan Th1/Th2 pada kehamilan, dimana pada preeklampsia telah tejadi pergerseran keseimbangan ke arah Th2 tidak terjadi dan berbalik arah pada Th1. Th2 menggambarkan karakteristik antiinflamasi dan Th1 sebagai pro inflamasi. Konsekuensi yang terjadi adalah menurunnya produksi IL-10 yang diproduksi oleh Th2. Penurunan produksi IL-10 berperan terhadap terjadinya plasentasi yang buruk dan memicu terjadinya aktifasi anti-angiogenesis dan hipoksia jaringan plasenta pada preeklampsia berat. Pada studi yang dilakukan Orange et al (2003) menunjukkan adanya penurunan bermakna kadar IL-10 pada preeklampsia dibandingkan dengan kehamilan normal. $^{1,2}$

Pada sebuah studi yang dilakukan pada mencit, didapatkan bahwa maternal hipoksia dapat memicu terjadinya produksi sFlt-1 dan sEng berlebihan oleh plasenta. Pada mencit dilakukan mutasi pada IL-10 (IL10-/-), didapatkan produksi anti-angiogenesis tersebut meningkat secara bermakna dan kemudian mengakibatkan terjadinya hipertensi, proses patologis pada ginjal, IUGR yang lebih berat dibandingkan mencit yang tidak dilakukan mutasi IL-10. ${ }^{3}$

IL-10 juga menunjukkan sifat protektif dalam melawan LPS bakteri atau angiotensin-II dalam memicu kerusakan vaskuler. Dapat dilihat pentingnya IL-10 dalam melindungi aktifitas vaskuler dan endovaskuler, yang 
berperan penting dalam fisiologi aliran darah dan ginjal. Dalam preeklampsia berat didapatkan patogenesis kelaianan invasi trofoblas dan buruknya remodeling arteri spiralis yang selanjutnya menyebabkan disfungsi endotel dan IL-10 mungkin berperan dalam hal tersebut. Studi tentang fungsi antiinflamasi IL-10 terhadap proses patologis pada ginjal dan terjadinya komplikasi akibat disfungsi endotel pada manusia belum pernah dilakukan. Studi ini mempelajari hubungan kadar IL-10 dengan serum kreatinin yang menggambarkan kondisi patologis ginjal dan terjadinya komplikasi pada pasien preeklampsia berat tipe dini yang dilakukan perawatan konservatif.

\section{BAHAN DAN METODE}

Penelitian ini dilakukan pada 30 wanita hamil dengan preeklampsia berat yang dilakukan perawatan konservatif. Pengambilan sampel IL-10 dilakukan melalui serum disimpan dalam pendingin bersuhu $-20^{\circ} \mathrm{C}$ untuk dikumpulkan dan dibuka setelah semua sampel terpenuhi. Konsentrasi IL-10 serum diukur dengan menggunakan kit ELISA (R\&D Quantikine kits (singlecytokine ELISAs; R\&D Systems, Minneapolis, MN 55413, USA Cat:HS100C, Lot: 319342, ED:10. 03. 15), dengan batas deteksi terendah $0,09 \mathrm{pg} / \mathrm{mL}$ dan standar pengukuran 0,39-50 pg $\mathrm{mL}$. Hasil luaran maternal dinilai setelah perawatan konservatif selesai sebelum dilakukan terminasi, meliputi klinis, laborat-orium dan terjadinya komplikasi.

\section{HASIL DAN PEMBAHASAN}

Karakteristik sampel dibagi menurut umur, pendidikan, paritas, Body Mass Index (BMI). Sesuai dengan tercantum pada tabel 1. Pembagian kelompok umur dibagi pada umur <20 tahun, 20-34 tahun, 235 tahun. Didapatkan mayoritas umur pasien preeklampsia yang dilakukan perawatan konservatif adalah umur 20-34 tahun (56,7\%). Umur 235 tahun terbanyak kedua, dengan frekuensi sebanyak $40 \%$. Karakteristik paritas, didapatkan mayoritas multigravida sebanyak 22 sampel $(73,3 \%)$. Karakteristik BMI sampel didapatkan mayoritas BMI pada kelompok BMI 25-29,9 kg/m2 yaitu 19 sampel $(63,3 \%)$. Riawayat keluarga dengan hipertensi diddapatkan pada $23,3 \%$ dari seluruh sampel.

Karakteristik pada sampel dicatat saat sampel datang dan sebelum diputuskan perawatan konservatif, meliputi variabel usia kehamilan saat diputuskan perawatan konservatif. Didapatkan hasil sesuai dengan tercantum pada Tabel 2. Didapatkan usia kehamilan pada preeklampsia tipe dini yang dilakukan perawatan kon- servatif adalah $31,93 \pm 1,08$ minggu. Didapatkan rerata kadar IL-10 0,71 $\pm 0,66$.

Tabel 1. Karakteristik sampel

\begin{tabular}{cll}
\hline Variabel & Frekuensi & Persentase \\
\hline Umur & & \\
$<20$ & 1 & 3,3 \\
$20-34$ & 17 & 56,7 \\
$\geq 35$ & 12 & 40 \\
\hline Pendidikan & & \\
SD & 4 & 13,3 \\
SMA & 26 & 86,7 \\
\hline Paritas & & \\
Primigravida & 8 & 26,7 \\
Multigravida & 22 & 73,3 \\
\hline BMI sebelum hamil & & \\
$<18,5$ & 1 & 3,3 \\
$18,5-24,9$ & 14 & 46,7 \\
$25-29,9$ & 14 & 46,7 \\
$\geq 30$ & 1 & 3,3 \\
\hline BMI saat hamil & & \\
$<18,5$ & 0 & 0 \\
$18,5-24,9$ & 3 & 10,0 \\
$25-29,9$ & 19 & 63,3 \\
$\geq 30$ & 8 & 26,7 \\
\hline Riwayat keluarga hipertensi & 23,3 \\
Ya & 7 & 76,7 \\
Tidak & 23 &
\end{tabular}

Sedangkan pada multiparitas, didapatkan karakteristik sampel yang mempunyai beberapa faktor resiko berkaitan dengan kejadian preeklampsia, sesuai tercantum dalam Tabel 2.

Tabel 2. Karakteristik sampel multigravida

\begin{tabular}{ll}
\hline \multicolumn{1}{c}{ Karakteritik sampel Multigravida } & Jumlah \\
\hline Umur ibu 25 tahun & 10 \\
Interval waktu dengan kehamilan & 5 \\
$\quad$ sebelumnya $>10$ tahun (primitua & \\
$\quad$ sekunder) & 2 \\
Riawayat abortus pada kehamilan & \\
$\quad$ sebelumnya & 2 \\
Kehamilan gemelli & 14 \\
BMI sebelum hamil $\geq 25 \mathrm{~kg} / \mathrm{m} 2$ & 17 \\
BMI saat hamil $\geq 25 \mathrm{~kg} / \mathrm{m} 2$ & 3 \\
Kehamilan pertama dari pasangan/patner & \\
$\quad$ baru & 4 \\
Riwayat preeklampsia pada kehamilan & \\
$\quad$ sebelumnya & \\
\hline
\end{tabular}

Karakteristik preeklampsia setelah perawatan konservatif didapatkan luaran yang dinilai setelah perawatan konservatif, sebelum dilakukan terminasi, meliputi umur kehamilan saat dilakukan terminasi kehamilan, lama perawatan konservatif, parameter klinis (tekanan 
darah), parameter laboratorium dan terjadinya komplikasi. Didapatkan data seperti ter-cantum dalam Tabel 3. Rerata umur kehamilan saat dilakukan terminasi adalah 34,37 $\pm 1,71$ minggu. Didapatkan rerata lama perawatan konservatif yaitu $13,37 \pm 9,98$ hari

Tabel 3. Karakteristik sebelum perawatan konservatif

\begin{tabular}{lllll}
\hline Variabel & Mean & SD & Min & Max \\
\hline Usia kehamilan & 31,93 & 1,08 & 29,00 & 33,00 \\
TD & & & & \\
$\quad$ Sistolik & 167,33 & 10,81 & 160,00 & 200,00 \\
$\quad$ Diastolik & 108,33 & 12,06 & 90,00 & 140,00 \\
Hb & 11,96 & 1,48 & 8.2 & 15.6 \\
Hct & 37,04 & 4,17 & 27,0 & 47,0 \\
Leukosit & 10,88 & 1,57 & 6,30 & 11,30 \\
Plt(x $\left.10^{3}\right)$ & 273,17 & 133 & 486 & 89,63 \\
Albumin & 3,11 & 0,41 & 2,20 & 4,00 \\
SGOT & 21,73 & 13,26 & 8 & 79 \\
SGPT & 12,63 & 7,25 & 5 & 43 \\
BUN & 9,35 & 4,34 & 2,00 & 20,00 \\
SK & 0,66 & 0,19 & 0,40 & 1,20 \\
LDH & 400,27 & 143,26 & 219 & 864 \\
Proteinuria & 3,53 & 0,63 & 2 & 4 \\
Kadar IL-10 & 0,71 & 0,66 & 0,12 & 3,61 \\
\hline
\end{tabular}

Tabel 4. Karakteristik setelah perawatan konservatif

\begin{tabular}{lllll}
\hline Variabel & Rerata & s.b & Min & Maks \\
\hline $\begin{array}{l}\text { Usia kehamilan } \\
\text { Tekanan darah }\end{array}$ & 34,37 & 1,71 & 31 & 37 \\
$\quad$ Sistolik & 154,00 & 14,76 & 130,00 & 190,00 \\
$\quad$ Diastolik & 100,67 & 12,30 & 80,00 & 140,00 \\
Trombosit & 236,57 & 91,36 & 50,00 & 450,00 \\
Albumin & 2,77 & 0,43 & 1,90 & 3,57 \\
SGOT & 24,82 & 13,53 & 8,00 & 68,00 \\
SGPT & 18,10 & 10,04 & 7,00 & 62,00 \\
BUN & 10,94 & 6,54 & 3,00 & 24,00 \\
SK & 0,83 & 0,29 & 0,50 & 1,60 \\
LDH & 497,18 & 220,82 & 255,00 & 1143,00 \\
\hline
\end{tabular}

Tabel 5. Luaran kehamilan

\begin{tabular}{lll}
\hline Luaran & & Hasil \\
\hline Berat lahir & Rerata (sd) & $2087,88 \pm 618,72$ \\
& $1000-<1500$ & $4(12,1 \%)$ \\
& $1500-<2000$ & $9(27,3 \%)$ \\
& $2000-<2500$ & $12(36,4 \%)$ \\
& 22500 & $8(24,2 \%)$ \\
Skor Apgar & 1 menit $<7$ & $14(42,4 \%)$ \\
& 5 menit $<7$ & $8(24,4 \%)$ \\
Kematian & & $4(12,1 \%)$ \\
perinatal & & $7(21,2 \%)$ \\
IUGR & gr. I-II & $3(9,1 \%)$ \\
RDS & gr. III-IV & $3(9,1 \%)$ \\
\multicolumn{2}{l}{ Didapatkan 3 kehamilan gemelli } \\
\hline
\end{tabular}

Berdasarkan data yang didapatkan sebelum dan sesudah perawatan konservatif, dilakukan uji komparasi terhadap kondisi sebelum dan sesudah perawatan konservatif untuk mengetahui kondisi sampel setelah perawatan konservatif dan untuk mengetahui perbaikan atau perburukan parameter-parameter preeklampsia perawatan konservatif dan tingkat kemaknaan secara statistik. Sesuai dengan distribusinya, dilakukan uji komparasi paired t-test atau uji Wilcoxon pada parameterparameter laboratorium dan didapatkan hasil seperti tercantum dalam tabel.

Tabel 6. Karakteristik perawatan konservatif

\begin{tabular}{|c|c|c|c|}
\hline Variabel & Rerata & s.b & $\mathrm{p}$ \\
\hline \multicolumn{4}{|l|}{ Sistolik } \\
\hline Sebelum & 167,33 & 10,81 & $<0,001$ \\
\hline Sesudah & 154,00 & 14,76 & \\
\hline \multicolumn{4}{|l|}{ Diastolik } \\
\hline Sebelum & 108,33 & 12,06 & 0,008 \\
\hline Sesudah & 100,67 & 12,30 & \\
\hline \multicolumn{4}{|l|}{ Trombosit } \\
\hline Sebelum & 273,17 & 89,62 & $<0,001$ \\
\hline Sesudah & 236,57 & 91,36 & \\
\hline \multicolumn{4}{|l|}{ Albumin } \\
\hline Sebelum & 3,11 & 0,41 & $<0,001$ \\
\hline Sesudah & 2,77 & 0,43 & \\
\hline \multicolumn{4}{|l|}{ SGOT } \\
\hline Sebelum & 21,73 & 13,26 & 0,230 \\
\hline Sesudah & 24,80 & 13,55 & \\
\hline \multicolumn{4}{|l|}{ SGPT } \\
\hline Sebelum & 12,63 & 7,25 & 0,003 \\
\hline Sesudah & 18,10 & 10,04 & \\
\hline \multicolumn{4}{|l|}{ BUN } \\
\hline Sebelum & 9,35 & 4,34 & 0,109 \\
\hline Sesudah & 10,94 & 6,54 & \\
\hline \multicolumn{4}{|l|}{ SK } \\
\hline Sebelum & 0,66 & 0,19 & $<0,001$ \\
\hline Sesudah & 0,83 & 0,29 & \\
\hline \multicolumn{4}{|l|}{ LDH } \\
\hline Sebelum & 400,27 & 143,26 & $<0,001$ \\
\hline Sesudah & 497,17 & 220,82 & \\
\hline
\end{tabular}

Pada studi ini dilakukan analisa korelasi antara IL-10 dengan albumin. Sebagai cut off level dipakai nilai hipoalbumin bila albumin $\leq 2,5 \mathrm{~g} \%$. Didapatkan hasil tidak terdapat hubungan antara IL-10 dengan terjadinya hipoalbumin. Sedangkan analisa hubungan IL-10 dengan SK dengan menggunakan regresi logistik. Didapatkan hasil tidak didapatkan hubungan antara IL-10 dengan peningkatan kadar $\mathrm{SK} \geq 1,02 \mathrm{mg} / \mathrm{dL}$

Tabel 7. Hubungan IL-10 dengan hipoalbumin

\begin{tabular}{llccc}
\hline & & $\mathrm{B}$ & $\mathrm{p}$ & $\mathrm{r}$ \\
\hline $\begin{array}{l}\text { Hipoalbumin } \\
2,5 \mathrm{~g} \%)\end{array}$ & $(\leq$ & 0,383 & 0,654 & 0,12 \\
\hline
\end{tabular}


Tabel 8. Hubungan IL-10 dengan SK

\begin{tabular}{lccc}
\hline & B & p & r \\
\hline SK & $-0,311$ & 0,621 & 0,12 \\
$(\geq 1,02$ & & & \\
$\mathrm{mg} / \mathrm{dL})$ & & & \\
\hline
\end{tabular}

Sedangkan analisa terhadap hubungan antara IL-10 dengan terjadinya komplikasi yang terjadi pada penelitian, yaitu terjadinya edema paru, sindroma HELLP, impending eklampsia. Dilakukan analisa menggunakan regresi logistik, untuk melihat hubungan antara IL-10 dengan masing-masing variabel. Dari hasil analisa statistik seperti tercantum dalam Tabel 9, tidak didapatkan hubungan antara IL-10 dengan terjadinya edema paru, sindroma HELLP, impending eklampsia

Tabel 9. Hubungan IL-10 dengan terjadinya komplikasi

\begin{tabular}{llrr}
\hline Variabel tergantung & \multicolumn{1}{c}{$\mathrm{B}$} & $\mathrm{p}$ & $\mathrm{R}$ \\
\hline Edema Paru & $-0,306$ & 0,835 & 0,004 \\
Sindroma HELLP & $-0,338$ & 0,785 & 0,006 \\
Impending eklampsia & $-0,023$ & 0,978 & 0.001 \\
Total komplikasi & 0,159 & 0,828 & 0,003 \\
\hline
\end{tabular}

Pada studi ini didapatkan rerata kadar IL-10 pada preeklampsia tipe dini $0,71 \pm 0,66$. Didapatkan koefisien varian dari data tersebut 93,21\% (standar deviasi/rerata $\mathrm{x} 100 \%$ ), menunjukkan data tersebut heterogen (>50\%), artinya rentang data tersebut mempunyai variasi yang lebar dan menunjukkan respon antiinflamasi yang sangat berbeda pada tiap sampel dengan preeklampsia. Kemungkinan hal tersebut selain dipengaruhi oleh reaksi gen fetal-maternal dan pengaruh lingkungan, dapat juga dikarenakan ada polimorfisme pada regio pengatur pada gen sitokin yang bertanggung jawab terhadap ekspresi kadar sitokin dan mungkin berkaitan dengan predisposisi dan/atau luaran atau klinis yang berbeda pada preeklampsia. ${ }^{4}$

Pada sebuah studi metanalisa tentang polimorfisme gen IL-10 didapatkan genotip IL-10-1082 GG lebih rendah pada preeklampsia dibandingkan kontrol. Pada studi lain menyebutkan genotip IL-10-2849 AA berkaitan dengan rendahnya produksi IL-10. Polimorfisme tersebut bergantung pada etnik dan menggambarkan insiden dan luaran penyakit. Perbedaan etnik tersebut mengakibatkan perbedaan alel dan distribusi genotip, akhirnya mengakibatkan perbedaan distribusinya terhadap kadar sitokin. Namun polimorfisme gen tersebut juga dipengaruhi oleh interaksi gen maternalfetal dan stimulus faktor lingkungan yang akhirnya mengakibatkan terjadinya beratnya gejala dan luaran penyakit. ${ }^{4}$ Belum ada studi di Indonesia yang mem- bandingkan kadar IL-10 dan polimorfismenya pada masing-masing suku/etnik di Indonesia.

Kadar IL-10 pada kehamilan normal berbeda dengan tidak hamil, berdasarkan teori bahwa pada kehamilan terdapat fenomena peningkatan $\mathrm{Th} 2$, sehingga sitokin Th2 dapat menghambat respon Th1 untuk memperbaiki kelangsungan hidup fetus. Studi yang dilakukan oleh Holmes et al, untuk mengetahui kadar IL-10 pada kehamilan normal, didapatkan kadar IL-10 pada kehamilan normal berbeda dengan secara bermakna dibandingkan dengan tidak hamil, baik pada umur kehamilan 12, 20 dan 35 minggu dan pada post partum $(\mathrm{p}<0,05, \mathrm{p}<0,01, \mathrm{p}<0,001 \text { dan } \mathrm{p}<0,01)^{5}$

Pada studi yang dilakukan Danianto (2015) tentang perbedaan kadar IL-10 pada preeklampsia tipe dini dibandingkan tipe lambat dan dibandingkan dengan kontrol dengan menggunakan sampel di RSUD Dr. Soetomo dan RSU Soewandhi Surabaya. Didapatkan hasil kadar IL-10 pada preeklampsia tipe dini lebih rendah bermakna dibandingkan dengan tipe lambat ( $\mathrm{p}<0,001)$ dan didapatkan lebih rendah dibandingkan dengan kehamilan normal pada rentang usia kehamilan yang sama $(\mathrm{p}<0,001){ }^{6}$

Salah satu komplikasi pada preeklampsia adalah gagal ginjal akut. Penanda gagal ginjal akut antara lain, serum kreatinin dan kemudian diukur GFR (Glommerular Filtration Rate), berkaitan langsung dengan perbandingan ekskresi kreatinin urin dan kreatinin (Ucr/Pcr). Pada studi dilakukan analisa hubungan IL-10 dengan proses patologis pada ginjal dengan penanda SK dan eGFR. Namun dari hasil analisa statistik didapatkan tidak didapatkan hubungan antara IL-10 dengan SK dan eGFR.

Serum kreatinin pada kehamilan normal menurun dibandingkan tidak hamil yaitu $0,5-0,7 \mathrm{mg} / \mathrm{dL}$, bila didapatkan nilai serum kreatinin 1,02 $\mathrm{mg} / \mathrm{dL}$ atau lebih maka dapat berkaitan dengan terjadinya kelainan pada ginjal dan diperlukan pemeriksaan lebih lanjut. Dalam studi ini memakai cut off level SK 1,02 mg/dL. Didapatkan 8 dari 30 pasien mempunyai kadar $\mathrm{SK} \geq$ $1,02 \mathrm{mg} / \mathrm{dL}$, didapatkan tiga dari delapan pasien dengan kadr IL-10 di atas rerata. Pada tiga orang pasien tersebut mempunyai faktor resiko antara lain kehamilan ganda, usia maternal > 35 tahun dan BMI saat hamil $\geq 30$ $\mathrm{kg} / \mathrm{m} 2$. Sedangkan pada tujuh sampel yang mengalami komplikasi maternal, didapatkan faktor resiko kehamilan ganda, usia maternal > 35 tahun, BMI saat hamil $\geq$ $30 \mathrm{~kg} / \mathrm{m} 2$ dan riwayat abortus pada kehamilan sebelumnya. Faktor-faktor tersebut yang memungkin-kan pengaruhnya terjadinya peningkatan serum kreatinin dan terjadinya komplikasi, walaupun kadar IL-10 pada pasien meningkat. 
Pada kehamilan kehamilan ganda berkaitan dengan terjadinya peningkatan tekanan darah diastolik yang meningkat $15 \mathrm{mmHg}$ pada $95 \%$ wanita dengan kehamilan gemelli dibandingkan pada $54 \%$ wanita dengan kehamilan satu. Peningkatan jumlah fetus dan peningkatan besar massa plasenta berpengaruh terhadap proses patologis pada plasenta. Studi pada kehamilan ganda meningkatkan produksi SFlt-1 dan penurunan PlGF serta peningkatan rasio sFlt-1/PlGF pada 58 dari 79 wanita dengan kehamilan ganda. Peningkatan tekanan darah tersebut yang mempengaruhi endotel ginjal yang berakhir pada perburukan fungsi ginjal. Pada kehamilan ganda juga berkaitan dengan terjadinya uropati obstruktif oleh karena pengaruh pembaesaran rahim sehingga sangat berpengaruh terhadap perubahan fungsi renal dan terjadinya komplikasi preeklampsia.

Sedangkan pada usia maternal $>35$ tahun berkaitan dengan penuaan endotel, yang berakibat terhadap luaran kehamilan dengan preeklampsia lebih buruk. Penuaan endotel tersebut berakibat pada kerusakan endotel terkait kehamilan dan mengakibatkan terjadinya endoteliosis sistemik yang berakibat pada proses patologis pada ginjal. Sehingga dalam kadar berapa pun kadar antiinflamasi, telah terjadi proses kerusakan endotel pada usia maternal $>35$ tahun. Studi yang dilakukan di Parkland hospital mendapatkan usia maternal > 35 tahun berkaitan dengan terjadinya komplikasi obstetri dan mortalitas dan morbiditas paeri-natal. Maternal dengan usia 35-39 tahun mempunyai resiko 2,5 kali dan usia >40 tahun mempunyai resiko 5,3 kali dibandingkan usia 20 tahun untuk terjadinya mortalitas maternal terkait dengan kehamilan. Sedangkan pada BMI $\geq 30$ $\mathrm{kg} / \mathrm{m} 2$ mempengaruhi produksi sitokin proinflamasi. Stres oksidan yang dikeluarkan oleh sel adiposit memicu keluarnya sitokin proinflamasi TNF- $\alpha$, IL-6 yang akhirnya memicu keluarnya endotel. Namun produksi TNF- $\alpha$ dan IL-6 sendiri memicu produksi IL10 dan sel-sel adiposit juga memicu keluarnya IL-10.

Plasenta merupakan masalah utama pada awal kehamilan yang menjadi penyebab utama terjadinya kerusakan sistemik maternal pada preeklampsia tipe dini. Untuk menjelaskan bagaimana inflamasi sistemik pada kehamilan, faktor dari plasenta yang belum diketahui pasti tersebut dapat memasuki sirkulasi maternal kemudian menyebabkan kerusakan maternal. Beberapa faktor tersebut harus dikeluarkan pada masa kehamilan dan meningkat secara atipikal ketika plasenta mengalami stres oksidatif. Salah satu karakteristik preeklampsia dan penyebab potensial pada preeklampsia adalah tidak terkontrolnya sistem imun maternal. Status proinflamasi berlebihan pada preeklampsia disebabkan oleh peningkatan produksi sitokin proinflamasi dan perununan produksi sitokin anti-inflamasi. Gejala seperti preeklampsia timbul pada mencit yang telah diberikan infus IL-4 dan TNF- $\alpha$ yang merupakan sitokin proinflamasi. ${ }^{7}$

Secara teori produksi IL-4 dan IL-10 sebagai antiinflamasi menurun produksinya. Studi pada mencit menunjukkan peran penting IL-10 pada preeklampsia dan sebagai proteksi terhadap preeklampsia. Pada mencit IL-10-/- menunjukkan gejala klinis seperti preeklampsia seperti hipertensi, proteinuria dan pertumbuhan janin terhambat. Serum darah IL-10-/- juga menunjukkan adanya pemicu produksi HIF-1 $\alpha$ pada plasenta yang mungkin dapat memicu produksi faktor anti-angiogenesis sFlt-1 dan sEng dan juga dapat memicu proses patologi pada renal dan nuruknya remodeling arteri spiralis. Pembentukan formasi tabung endovaskuler juga terganggu secara bermakna dibandingkan kontrol. ${ }^{7}$

Kemungkinan lain tidak terdapat hubungan antara IL-10 dengan proses patologis ginjal dan terjadinya komplikasi adalah pengaruh sitokin proinflamasi terhadap kenaikan IL-10 dan kemungkinan rasio Th1/ Th2 yang lebih berpengaruh daripada kadar masingmasing proinflamasi dan antiinflamasi. Studi yang dilakukan oleh Dong et al, untuk mengetahui adanya ketidakseimbangan antara $\mathrm{T} 1 / \mathrm{Th} 2$ pada preeklampsia. Untuk mengetahui perubahan kadar Th1 dilakukan pemeriksaan sitokin IL-2 dan TNF- $\alpha$ dan IL-10 yang mewakili Th2 dan rasio antara Th1/Th2 (yaitu IL-2/IL10 dan TNF- $\alpha /$ IL-10) pada plasenta wanita yang hamil dengan preeklampsia dan hipertensi gesteasional. Walaupun pada preeklampsia secara teori didapatkan peningkatan faktor proinflamasi dan penurunan antiinflamasi, namun hasil yang didapatkan tidak didapatkan perbedaan bermakna antara kadar IL-2, IL-10 dan TNF- $\alpha$ antara kehamilan dengan preeklamp-sia, hipertensi gestasional dan kehamilan normal $(\mathrm{p}>0,05)$. Namun pada pemeriksaan rasio IL-12/IL-10 dan TNF$\alpha /$ IL-10 yang mewakili rasio $\mathrm{Th} 1 / \mathrm{Th} 2$, didapatkan peningkatan rasio bermakna pada kehamilan dengan preeklampsia dengan kehamilan normal ( $\mathrm{p}=0,035$ dan $\mathrm{p}=0,005)$, sedangkan rasio antara pre-eklampsia dengan kehamilan normal dan preeklampsia dengan hipertensi gestasional tidak didapatkan perbedaan bermakna $(p>0,005){ }^{8}$

Pada studi tersebut di atas, membuktikan tidak hanya penurunan IL-10 (mewakili Th2) saja yang berperan, namun disertai dengan peningkatan faktor proinflamasi yang dikeluarkan Th1. Peningkatan Th1 dan penurunan Th2 tersebut yang membuat terjadinya ketidakseimbangan yang akhirnya membuat kerusakan trofoblas dan endotel vaskuler seperti yang terjadi pada preeklampsia. Dan dapat diasumsikan bahwa ketidakseimbangan kadar sitokin tersebut mewakili ketidak seimbangan Th1/Th2, lebih dapat menilai prognosis 
kehamilan, daripada menilai masing-masing kadar sitokn tersebut secara terpisah. ${ }^{8}$

Studi peran IL-10 tidak hanya pada preeklampsia, namun berperan terhadap terjadinya abortus. Beberapa studi melaporkan rendahnya kadar IL10, rendahnya sel yang memproduksi IL-10 dan meningkatnya rasio sitokin Th1/IL-10 pada wanita dengan abortus spontan. Studi lain, yaitu pada wanita dengan kegagalan berulang kali pada fertilisasi in vitro, menunjukkan peningkatan rasio TNF- $\alpha+/+/$ IL-4+/+ dan rasio TNF- $\alpha+/+/$ IL-10+/+. Hal tersebut juga dilaporkan pula terjadi pada wanita yang mengalami keguguran berulang. ${ }^{7}$

Selain faktor inflamasi, terdapat dua grup faktor kandidat yang saling berkaitan yang berperan memasuki sirkulasi maternal pada preeklampsia, yaitu pertama, grup growth factors, yang terdiri dari soluble receptor atau sitokin inflamasi; kedua, produk stres oksidatif plasenta, termasuk debris plasenta dan atau faktor lain. Kandidat kuat saat ini berperan pada preeklampsia adalah soluble receptor untuk VEGF yang dikenal dengan sFlt-1. Molekul ini bekerja dengan menetralisir aktifitas angiogenik VEGF dan PIGF. VEGF merupakan faktor penting untuk endotel, oleh karena itu bila terjadi penghambatan sistemik akan menyebabkan disfungsi endotel secara luas. Hal tersebut telah terbukti melalui studi pada hewan coba dan manusia. Pemberian infus sFlt-1 pada tikus menyebabkan endoteliosis glomerular, hipertensi dan proteinuria. Pada percobaan klinis, telah dilakukan pemberian antibodi monoklonal VEGF (yang menyerupai fungsi anti-angiogenesis sFlt-1) untuk terapi kanker, hipertensi dan proteinuria merupakan efek samping yang paling sering terjadi. ${ }^{9}$

Sindroma maternal dan bentuk klinis preeklampsia ditandai adanya disfungsi endotel dan mikroangiopati, dengan target organ antara lain otak (ditandai dengan terjadinya kejang atau eklampsia), hepar (terjadinya sindroma HELLP) atau ginjal (terjadi endoteliosis glomerolus dan proteinuria). Beberapa studi yang terbaru mencoba membuat hipotesis terhadap manifestasi klinis dan komplikasi yang terjadi pada preeklampsia seperti yang tersebut di atas, kemudian memberikan kesimpulan dugaan adanya peran ketidakseimbangan pro-angiogenesis dan anti-angiogenesis pada sirkulasi. Dua faktor anti-angiogenesis dikeluarkan oleh plasenta yang mendapatkan perhatian adalah selain sFlt-1 juga soluble Endoglin (sEng) yang mengalami peningkatan dan faktor pro-angiogenesis yang mengalami penurunan pada preeklampsia yaitu VEGF dan PlGF. ${ }^{10}$

Didapatkan dua studi yang menganalisa tentang hubungan faktor angiogenesis dengan luaran maternal pada preeklampsia. Sebuah studi mempelajari kadar
sVEGFR-1 (sFlt-1) dan hubungannya dengan luaran preeklampsia, dengan jumlah sampel 61 pasien hamil normal dan 61 pasien dengan preklampsia. Didapatkan kadar plasma sVEGFR-1 meningkat pada preeklampsia dibandingkan kehamilan normal $(\mathrm{p}<0,001)$ didapatkan peningkatan kadarnya pada preeklampsia tipe dini dibandingkan tipe lambat $(\mathrm{p}=0,005)$ dan didapatkan peningkatan kadarnya pada preeklampsia berat dibandingkan preklampsia ringan. Sedangkan pada luaran maternal, didapatkan korelasi positif antara kadar sVEGFR-1 dengan derajat proteinuria $(\mathrm{r}=0,4 ; \mathrm{p}=$ $0,002)$ dan korelasi negatif antara sVEGFR-1 dengan hitung platelet $(\mathrm{r}=0,3 ; \mathrm{p}=0,04)$, berat badan janin $(\mathrm{r}=$ $0,6 ; \mathrm{p}<0,001)$, terjadinya kesesuaian berat badan janin dengan umur kehamilan $(\mathrm{r}=0,4 ; \mathrm{p}<0,001)$ dan umur kehamilan saat persalinan $(\mathrm{r}=0,5 ; \mathrm{p}<0,001)$. Sedangkan hubungan dengan faktor resiko yang lain, didapatkan kadar sVEGFR-1 lebih besar secara bermakna pada wanita dengan riwayat terjadi preeklampsia pada kehamilan sebelumnya dibandingkan dengan tidak didapatkan riwayat. Didapatkan korelasi negatif konsentrasi sVEGFR-1 dan umur kehamilan saat terjadinya preeklampsia $(\mathrm{r}=0,5 ; \mathrm{p}<0,001) .{ }^{11}$

Sedangkan studi lain yang menghubungkan kadar PIGF dengan terjadinya luaran maternal dan fetal buruk dan sangat buruk pada kehamilan yang diduga akan terjadi preeklampsia dan IUGR. Luaran maternal buruk diidentifikasikan terjadinya preeclampsia berat, berat neonatus kecil menurut umur kehamilan, terjadi persalinan elektif oleh karena indikasi fetal dan mater-nal. Luaran maternal sangat buruk diidentifikasi-kan terjadinya komlikasi preeklampsia meliputi indroma HELLP, eklampsia, kematian janin dalam kandungan, terminasi persalinan karena IUGR, berat neonatus neonatus sangat rendah menurut usia kehamilan atau terjadinya persalinan elektif sebelum usia kehamilan 34 minggu oleh karena komplikasi maternal dan fetal. Didapatkan kadar PIGF lebih rendah pada kehamilan dengan preeklampsia berat dibanding-kan normal ( $\mathrm{p}=$ $0,02)$ dan pada luaran maternal buruk ( $\mathrm{p}<0,001)$ dan dengan kadar PlGF $<12 \mathrm{pg} / \mathrm{mL}$ didapatkan luaran maternal sangat berat/buruk pada $96 \%$ kasus (24/25). Resiko terjadi luaran maternal buruk terjadi pada kadar PlGF yang terendah $(\mathrm{OR}=216,95 \%$ CI [18-2571] $)$ dibandingkan dengan kadar PlGF rerata median tertinggi $(\mathrm{OR}=17,95 \% \mathrm{CI}[3-94]) .^{12}$

Tidak adanya hubungan antara IL-10 dengan luaran maternal pada studi ini, membuka peluang untuk studi lain tentang faktor angiogenesis yang mungkin berperan selain faktor inflamasi, untuk terjadinya gejala klinis dan luaran fetal dan maternal pada preeklampsia. Dapat diteliti masing-masing faktor pro-angiogenesis dan antiangiogenesis maupun rasionya terhadap luaran fetal dan maternal pada preeklampsia. 
Selain itu banyak faktor yang mempengaruhi kadar sitokin inflamasi, yaitu polimorfisme gen yang tidak diteliti pada studi ini. Polimorfisme tersebut dapat mempengaruhi tinggi rendahnya kadar IL-10 dan mungkin dapat mempengaruhi kondisi klinis dan luaran maternal pada preeklampsia. Dan belum ada penelitian yang mempelajari tentang polimorfisme gen IL-10 terhadap kadar IL-10 dan luaran maternal dan fetal pada preeklampsia.

Pada penelitian ini tidak dinilai kadar proinflamasi terhadap terjadinya klinis dan terjadinya komplikasi pada preeklampsia, sehingga tidak dapat dinilai dugaan pengaruh sitokin proinflamasi terhadap preeklampsia tipe dini dan hubungannya rasio proinflamasi/antiinflamasi terhadap luaran maternal, karena pada studistudi sebelumnya didapatkan hasil yang bervariasi, didapatkan kadar IL-10 yang berbeda-beda antara preeklampsia dan kontrol, kadarnya dapat menurun atau tidak didapatkan perbedaan. Hal tersebut dikarenakan kadar IL-10 pada masing-masing individu berbeda, dapat dilihat dari kadar IL-10 pada studi ini yang mempunyai heterogenitas yang besar dan masih belum ada cut off kadar IL-10 pada kehamilan normal dan kehamilan dengan preeklampsia terutama untuk sampel wanita hamil di Indonesia.

Pada studi yang dilakukan sebelumnya, didapatkan kadar IL-10 yang tidak berbeda bermakna, namun didapatkan nilai rasio kadar proinflamasi/antiinflamasi berbeda bermakna antara preeklampsia dan kehamilan normal. Sehingga dapat disimpulkan bahwa perlu dinilai kadar proinflamasi dan dibandingkan dengan kadar antiinflamasi (rasio), karena kadar sitokin pada masingmasing individu berbeda dan kemungkinan rasionya lebih berperan daripada kadar masing-masing proinflamasi maupun antiinflamasi, karena tidak hanya faktor antiinflamasi yang menurun saja yang dikaitkan dengan terjadinya preeklampsia, namun faktor proinflamasi juga mempengaruhi terjadinya preeklamp-sia dan kemudian pergeseran diantara faktor proinflamasi/antiiflamasi yang menggambarkan pergeseran keseimbangan Th1/Th2 mungkin lebih berperan terhadap terjadinya preeklampsia. Rasio yang didapat tersebut nantinya akan menggambarkan pergeseran ke arah proses proinflamasi seperti yang didapatkan pada preeklampsia. Selain itu juga perlu adanya penelitian lebih lanjut tentang pengaruh kadar pro-angiogenesis dan anti-angiogenesis serta pengaruhnya terhadap preeklampsia, untuk membuktikan adanya pengaruh faktor-faktor angiogenesis terhadap preeklampsia, kedekatannya sebagai faktor prognostik terhadap terjadinya preeklampsia maupun luaran preeklampsia dibandingkan faktor-faktor inflamasi.

\section{SIMPULAN}

Rerata kadar IL-10 pada preeklampsia berat tipe dini yang dilakukan perawatan konservatif adalah $0,71 \pm$ 0,66. Tidak ada hubungan antara IL-10 dengan kadar serum kreatinin dan terjadinya komplikasi preeklampsia berat tipe dini.

\section{DAFTAR PUSTAKA}

1. Orange S, Horvath $\mathbf{J}$ and Hennessy A. Preeclampsia Is Associated with a Reduced Interleukin-10 Production from Peripheral Blood Mononuclear Cells. Hypertension in Pregnancy. 2003;22:1-8.

2. Kalkunte S, Nevers T, Norris WE and Sharma S. Vascular IL-10: a protective role in preeclampsia. Journal of Reproductive Immunology. 2011;165-9.

3. Lai Z, Kalkunte S and Sharma S. A Critical Role of Interleukin-10 in Modulating Hypoxia-Induced Preeclampsia-Like disease in mice. Journal of the American Heart Associaton. 2011;57:505-14.

4. Daher S, Sass N, Oliveira LG and Mattar R. Cytokine Genotyping in Preeclampsia. American Journal of Reproductive Immunology. 2006;55: 130-5.

5. Holmes V, Wallace J, Gilmore W, Mcfaul P and Alexander H. Plasma levels of the immunomodulatory cytokine interleukin-10 during normal human pregnancy: a longitudinal study. Cytokine. 2003;21:265-9.

6. Danianto A. Perbandingan IL-10 pada pasien preeklampsia berat tipe dini dan tipe lambat. 2015.

7. Chatterjee $\mathrm{P}$, Chiasson VL, Bounds $\mathrm{KR}$ and Mitchell BM. Regulation of the anti-inflammatory cytokines interleukin-4 and interleukin-10 during pregnancy. Frontiers in immunology. 2014;5(253):1-6.

8. Dong $\mathrm{M}, \mathrm{He} \mathrm{J}$, Wang Z, Xie X and Wang $\mathrm{H}$. Placental imbalance of Th1- and Th2-type cytokines in preeclampsia. Acta Obstet Gynecol Scand. 2005;84:788-93.

9. Borzychowski A, Sargent I and Redman C. Inflammation and pre-eclampsia. Elsevier: Seminars in Fetal \& Neonatal Medicine. 2006;11:3006316.

10. Powe CE, Levine RJ and Karumanchi A. Preeclampsia, a Disease of the Maternal Endothelium: The Role of Antiangiogenic Factors and Implications for Later Cardiovascular Disease. Circulation, Jornal of American Heart Association. 2011;123:2856-69.

11. Chaiworapongsa T, Romero R, Espinoza J, Bujold E, Kim YM, Goncalves LF, et al. Evidence supporting a role for blockade of the vascular 
endothelial growth factor system in the pathophysiology of preeclampsia. American Journal of Obstetrics and Gynecology. 2004;190: 1541-50.

12. Sibiude J, Guibourdenche J, Dionne MD, Ray CL, Anselem O, Serreau R, et al. Placental Growth
Factor for the Prediction of Adverse Outcomes in Patients with Suspected Preeclampsia or Intrauterine Growth Restriction. Plos One. 2012;7 (11):1-8. 